\title{
A Unilateral Climate and Supply Market Model
}

\author{
Eike Blume-Werry, Martin Koller, and Martin Everts
}

\begin{abstract}
In the midst of its respective energy transitions, the European power sector faces several challenges. Low levels of both European Union Emissions Trading Scheme (EU ETS) allowance prices and wholesale power prices fuelled concerns over drivers for decarbonisation and long-term generation adequacy. Whilst some countries have introduced capacity remuneration mechanisms to ensure generation adequacy, reforming the EU ETS has proven to be difficult. This paper proposes a unilateral approach by a state introducing a $\mathrm{CO}_{2}$ levy that internalises and prices $\mathrm{CO}_{2}$ at a national level. The suggested climate and supply market model thereby incentivises and rewards production from $\mathrm{CO}_{2}$-neutral sources during times when it does not cover the targeted share of production. Prior to describing the model in detail, this paper discusses the theoretical policy steering background and the problems associated with current energy policies. For a broader picture, other $\mathrm{CO}_{2}$ taxation models are briefly presented. This is followed by a discussion on the legal aspects of the model, its compatibility with international as well as EU law. The model is explored further by using Switzerland as an example, showing that a crosssector carbon price can be implemented at acceptable costs for consumers. Last but not least, the paper examines varieties of the model and the adaption potential for European countries.
\end{abstract}

Keywords Border tax $\cdot$ Carbon tax $\cdot$ Climate policy $\cdot \mathrm{CO}_{2}$ levy $\cdot$ Emission trading $\cdot$ Energy policy $\cdot$ EU ETS $\cdot$ Security of supply

E. Blume-Werry $(\bowtie)$

TU Wien, Vienna, Austria

M. Koller · M. Everts

Axpo Holding AG, Baden, Switzerland

(C) The Author(s) 2019 


\section{Energy Policy and the Concept of Direct and Multiple Steering}

It is the objective of modern energy policies to decarbonise without jeopardising other policy objectives. Within this context, one usually refers to the energy policy objective triangle of (1) security of supply, (2) affordability and (3) sustainability. In order to tackle climate change and fight global warming, governments strive to reduce emissions and mitigate respective risks (Doukas et al. 2008, p. 362; Nikas et al. 2018). Carbon dioxide $\left(\mathrm{CO}_{2}\right)$ in particular has become a common standard to measure the sustainability of a given system and quantify emission growth or reduction. $\mathrm{CO}_{2}$ is emitted by a variety of sources from different sectors, the power and transport sector being amongst the most prominent. Depending on the sector, there are different energy policies and strategies to initiate emission reductions.

Focusing on the power sector, one can differentiate between two theoretical policy concepts: direct and multiple steering. The former centres around the idea of pricing and internalising $\mathrm{CO}_{2}$ or, more generally, greenhouse gas emission costs. In practice, this can be put into effect by introducing a $\mathrm{CO}_{2}$ tax and/or an emission trading system such as the European Union Emissions Trading Scheme (EU ETS). Given the declared objective of decarbonisation, this approach can be seen as plausible and straightforward. Putting a price on $\mathrm{CO}_{2}$ emissions should reduce the overall output and thus give rise to further decarbonisation. This approach directly targets $\mathrm{CO}_{2}$ emissions, which is why we refer to it as 'direct steering'.

In contrast, an indirect steering method would indirectly work towards achieving the same objective, for example, by setting other incentives to reduce emissions or promote alternatives, which entail less or no emissions. Examples would include taxes on emission-intensive fuels or support for renewables.

If multiple policy measures coincide and interact with the common objective of reducing emissions, one speaks of a multiple steering model (Everts et al. 2016, pp. 119-120). ${ }^{1}$ For example, a $\mathrm{CO}_{2}$ tax and trading system can be a part of a multiple steering model. Indeed, most governments nowadays have a range of policies in place that not only price $\mathrm{CO}_{2}$ but also incentivise emission reduction in other ways. It is an advantage of this multiple steering model that policymakers have greater control over emission reduction contributions of different sectors, technologies used and general concepts. There are, however, several problems with those designs which currently prevail.

\footnotetext{
${ }^{1}$ Multiple steering models usually include direct and indirect measures.
} 


\section{Current Issues of the EU ETS}

There is an extensive body of literature on the weak performance of the EU ETS and the continuous drop in price of allowances since the financial crisis, from about $30 \mathrm{EUR} / \mathrm{tCO}_{2}$ to below $5 \mathrm{EUR} / \mathrm{tCO}_{2}{ }^{2}{ }^{2}$ The low allowance price level has led to circumstances in which there exists great uncertainty as to whether the EU ETS is still and can be a main driver for decarbonisation, despite being designed to fulfil exactly this role (Marcu et al. 2016, pp. 7-11). In general, scholars regard the price level as too low to fulfil the intended functions (Abrell et al. 2016, p. 2; Rogge et al. 2011; European Commission 2014). It has been argued that at the current price level, costs of negative externalities stemming from carbon emissions are no longer properly internalised (Carbon Market Watch 2015, p. 4). Further, the price of allowances is too low to trigger investments in low carbon technologies and facilitate innovation (Carbon Market Watch 2015, p. 4; Hepburn et al. 2016, p. 1; Rogge et al. 2011).

This points towards the prevailing problems of the EU ETS and a necessity for reform. However, reforming the EU ETS has proven a difficult political matter, given the diverse interests of the stakeholders and parties involved. Currently, there is an ongoing reform process of the EU ETS for which the European Parliament voted and on which the European Council recently agreed a position (European Council 2017). However, observers remain sceptical that the proposed changes will be sufficient to end the run of very low allowance prices (Boffey 2017; Rattay 2017).

This run of very low allowance prices (on average $6.2 \mathrm{EUR} / \mathrm{tCO}_{2}$ during the last 5 years $)^{3}$ has also had subsequent effects. It is part of the concept of the multiple steering model to maintain some level of price neutrality with respect to wholesale power prices. But $\mathrm{CO}_{2}$ pricing systems such as the EU ETS have a price-increasing effect on wholesale power prices, whilst the deployment of low marginal cost renewables has a price-decreasing effect, which is why both policies together have the potential of retaining overall price neutrality. Power prices have fallen drastically since the financial crisis, and the price decline of $\mathrm{CO}_{2}$ allowances and the deployment of low marginal cost renewables have been found to be the most contributing factors to this wholesale power price drop in Germany (Bublitz et al. 2017, p. 330; Everts et al. 2016, p. 122; Hirth 2016, p. 11).

This development of wholesale power prices has in turn increased the focus on the so-called missing money problem ${ }^{4}$ - a problem which might threaten the longterm security of supply. If there is no investment rationale for investments in flexible

\footnotetext{
${ }^{2}$ Koch et al. provide a concise overview of current state of research on the EU ETS and the causes of the price drop (Koch et al. 2014).

${ }^{3}$ Average ICE EUA futures 2012-2016 (Intercontinental Exchange 2017).

${ }^{4}$ The 'missing money problem' describes a situation in an energy-only market where low power prices and few price spikes do not provide sufficient (long-term) investment incentives in new (flexible) generation capacity. For a closer examination of the missing money problem, see Crampton and Stoft (2006), Joskow (2008) and Newbery (2016).
} 
generation capacity to balance intermittent renewable production or in conventional backup capacity, security of supply is threatened. As a consequence, many governments have recently introduced mechanisms to provide market participants with more incentives for building or maintaining generation capacities in order to guarantee that power demand can be met at all times. In theory, there should be no need for such market interventions, as the energy-only market should provide sufficient incentives for new capacity with scarcity price spikes. Therefore some see capacity remuneration mechanisms ${ }^{5}$ as market distortions (European Commission 2016; Hancher et al. 2015).

It should be noted at this point that the investment cycles in the energy industry are generally characterised by their long-term nature and high capital costs. Power plants have long life times with high upfront costs. The high capital intensity amplifies the impact of investment cycle changes and raises the risk of excessive or insufficient capacities (Lu et al. 2015, p. 3242). A low-price outlook as well as regulatory uncertainties may exacerbate this effect. This, combined with technology innovations and doubts over future market designs, has made traditional investments in power plants with an expected lifetime of half a century or longer rather complex.

The dearth in investment incentives has also been identified by the European Commission as a market failure. It is commonly acknowledged that further policy measures targeting emission reductions and addressing concerns on (long-term) investment incentives are needed (European Commission 2016, p. 4). Electricity supply is now more than ever a vital good in modern societies and is also in liberalised markets regarded as a public good ${ }^{6}$ (Abbott 2001, pp. 31-33; De Vries and Hakvoort 2003, p. 2; Finon and Pignon 2008, p. 3). Insufficient investments to guarantee long-term security of supply can thus be seen as a market failure, and capacity mechanisms represent a regulatory market intervention to address the issue.

\section{Existing Carbon Taxation Models}

The following section briefly presents and examines other $\mathrm{CO}_{2}$ taxation models, namely, a differential taxation model, the use of border tax adjustments and the current $\mathrm{CO}_{2}$ taxation model of the United Kingdom.

\footnotetext{
${ }^{5}$ Whilst capacity remuneration mechanisms can take different forms, they generally provide monetary payments towards generators for available generation capacity.

${ }^{6} \mathrm{~A}$ public good is commonly defined by the characteristics of nonrivalry and non-excludability, i.e. additional consumers add no additional costs (zero marginal costs) or reducing the good's availability for others and people cannot be excluded from consuming the good.
} 


\subsection{Differential Taxation}

Cottier et al. propose a $\mathrm{CO}_{2}$ taxation model described as differentiated electricity tax (Cottier et al. 2014b). It aims to replace renewable support schemes and act as a steering system. They suggest different tax rates based on the technology used to generate electricity, aiming not only to reduce consumption but also to promote renewables. Renewable energy sources would profit from exemptions, and tax rates for electricity produced from non-renewable sources would depend on their carbon intensity (Cottier et al. 2014b, p. 3). Guarantees of origin (or alternatively specifically designed renewable energy certificates) occupy a central role by determining the corresponding tax rate. The scholars discuss four main different varieties of the model in detail with respect to the legal considerations they entail. ${ }^{7}$

They find that offering exemptions in their model only for domestic renewable electricity - effectively treating domestic and foreign production differently-would most likely constitute discrimination under the GATT (Holzer et al. 2017, pp. 380-381). One approach which could circumvent this is introducing additional requirements and constraints for imported electricity eligible for tax exemptions. Yet, even in that case, compliance with WTO law remains uncertain, depending on the exact criteria (Holzer et al. 2017, p. 382). A central issue associated with also offering unrestricted exemptions for foreign renewable production is the significant availability of guarantees of origin at very low prices in the EU, especially from Nordic hydropower. Producers could simply purchase those guarantees of origin instead of paying the - it is assumed-costlier carbon tax.

In contrast to the proposed climate and supply market model with one uniform $\mathrm{CO}_{2}$ levy, the differentiated electricity tax aims to tax electricity at different rates depending on the electricity source. Even though both models use guarantees of origin, their functions differ. In the proposed climate and supply market model, the guarantees act as a source of additional income for renewable producers due to their-at times - significant increase in value. Cottier et al.'s legal analysis of their model regards a limitation of tax exemptions only for domestic renewable electricity as problematic, whereas the structure of the proposed climate and supply market model enables a lawful increase in value of exclusively domestic guarantees of origin from $\mathrm{CO}_{2}$-neutral production.

\subsection{Carbon Tax with Border Tax Adjustments}

Border tax adjustments (BTA) have in recent years been increasingly discussed in relation to enforcing an environmental tax on imported goods within WTO law. A particular focus of research has been the interplay of emission trading schemes and

\footnotetext{
${ }^{7}$ See Holzer et al. (2017) and Cottier et al. (2014a, b).
} 
BTA and how BTA can be used to avoid carbon leakage. ${ }^{8}$ Regarding the power sector, one could introduce an environmental $\mathrm{CO}_{2}$ tax on power generation. BTA could then be used to tax imports in order to prevent competitive disadvantages for domestic production. If the tax shall depend on the $\mathrm{CO}_{2}$ intensity of the technology used to generate the electricity, one effectively applies a differential taxation model such as the aforementioned model.

In practical terms, one aspect which comes hand in hand with the problem is that the origin of electricity is not always known and guarantees of origin are often only issued for renewables. Guarantees of origin would need to be introduced for all technologies and, possibly, also certify the $\mathrm{CO}_{2}$ footprint of the electricity. It remains an open question how imports without guarantees of origin would be handled. A subsequent question in this cross-border context is if one can legally differentiate between electricity produced from $\mathrm{CO}_{2}$-neutral sources (green electricity) and electricity produced from unknown or fossil energy sources (grey electricity). As a matter of fact, there exists significant legal debate amongst scholars as to whether green and grey electricity are considered 'like' or 'unlike' products under WTO law-thus far this question has not been subject to WTO jurisprudence (Holzer et al. 2017, p. 373; Kreiser et al. 2015, p. 167).

If all electricity was considered a 'like' product independent of its method of production and origin, equal treatment is required from a legal perspective. In this case, imported grey electricity could not be treated less favourably than domestically produced green electricity. ${ }^{9}$ A flat tax on all electricity generation would fail to set incentives for low or carbon-free production. In case grey and green electricity are deemed 'unlike' products, a taxation model taxing them at different rates and using BTA seems theoretically feasible. However, a unilateral implementation of such a market design would face the aforementioned practical issue of a significant availability of renewable guarantees of origin at comparably low prices in the EU. Treating domestic electricity from $\mathrm{CO}_{2}$-neutral sources differently than that from foreign $\mathrm{CO}_{2}$-neutral sources would-as discussed-most likely contravene GATT rules.

\subsection{United Kingdom: Carbon Price Floor}

In 2013, the British government's Department of Energy and Climate Change (DECC) established a carbon price floor for electricity generation taxing fossil fuels used to generate electricity. It can be described as a 'top-up' of the EU ETS. The carbon price floor was initially introduced at $16 \mathrm{GBP} / \mathrm{tCO}_{2}$ and was supposed to

\footnotetext{
${ }^{8}$ See Ismer and Neuhoff (2007), Kuik and Hofkes (2010), Panezi (2015).

${ }^{9}$ It should be noted that Art. XX GATT on exceptions may leave some room for policy measures, potentially enabling a justification of violation of the non-discrimination rules. See Cottier et al. (2014c, pp. 34-37), for a detailed discussion.
} 
reach $30 \mathrm{GBP} / \mathrm{tCO}_{2}$ in 2020 and $70 \mathrm{GBP} / \mathrm{tCO}_{2}$ in 2030 (in real 2009 prices). To this end, the government charges power generators a top-up of the EU ETS called Carbon Price Support (CPS) making up the difference between the floor price and the EU ETS allowance price. The amount of this CPS is announced with budget statement by the British Treasury 2 years in advance.

Due to the lower than expected EU ETS allowance prices, the CPS was frozen at $18 \mathrm{GBP} / \mathrm{tCO}_{2}$ until 2021 in order to limit the competitive disadvantage faced by businesses and prevent electricity bills from rising (HM Revenues and Customs 2014, p. 1; HM Treasury 2016).

The carbon price floor was introduced with the intention of correcting the market distortions created by the low EU ETS prices. It was supposed to underpin the price of carbon at a level that drives low carbon investment (Ares and Delebarre 2016, p. 3). The mechanisms contributed to a significant drop in electricity generation from coal-fired power plants due to higher costs associated with such generation, which in turn helped to reduce emissions (Clark 2017).

Analysing the design of the carbon price floor, it is essential to highlight that the carbon price floor affects only producers in Great Britain. Electricity imports to Great Britain are not subject to the carbon price floor; charging producers abroad would most likely violate the General Agreement on Tariffs and Trade (GATT) (in particular Article III). ${ }^{10}$ The subsequent competitive disadvantages for electricity producers in Great Britain compared with those abroad are rather limited due to the relatively low interconnector capacity of Great Britain with other countries (4GW) as a result of its natural geographically isolated island location (Ofgem 2017). In a more interconnected market, the design of the carbon price floor that only charges national producers would not be sensible as it would disadvantage national production disproportionately. This is also the reason why Northern Ireland is exempted from the carbon price floor (Foster in Sync Ni 2013).

Currently there are ongoing discussions about the future of the carbon price floor. ${ }^{11}$ There are both calls to phase out the mechanism as well as calls to maintain it. Of particular interest, there are studies that project the carbon price floor to lead to an overall increase in emissions. An increased interconnection capacity with planned interconnectors to mainland Europe and Iceland might, together with the carbon price differential, cause European-wide emissions to rise as gas-fired generation in Britain might be undercut by coal-fired generation in mainland Europe (Aurora Energy Research 2016, p. 2). In light of Brexit, there remains policy uncertainty regarding the future of interconnectors and the United Kingdom's participation in the EU ETS (Howard 2016, p. 11). The UK Government has, however, signalled its intention to maintain the carbon price floor mechanism at its current rate until 2021 (HM Treasury 2016).

\footnotetext{
${ }^{10}$ The role and classification of electric power as a good under WTO law and the subsequent legal implications are subject to substantial legal debate. Cottier et al. (2014c, pp. 34-37) provide an overview of handling electricity under WTO law, and Horn and Mavroidis (2011) discuss the legality of Border Tax Adjustments for climate purposes. It is generally agreed that $\mathrm{CO}_{2}$ taxation regimes not limited to domestic production may easily violate WTO (GATT) rules.

${ }^{11}$ For an overview see the recent research note by Policy Exchange (Howard 2016).
} 
The example of $\mathrm{CO}_{2}$ taxation in Great Britain and the model proposed by Cottier et al. illustrate the economic and legal constraints of $\mathrm{CO}_{2}$ steering models. Reforms on a European level have proven difficult, levying only domestic power producers results in competitive disadvantages, and taxes on imports are likely to violate international law. For countries with a low share of interconnector capacity, a carbon price floor such as the British model-levying only domestic productioneffectively counters low EU ETS allowance prices and can (re)establish carbon prices as a driver for decarbonisation. The networks of most European countries are, however, much more deeply integrated and connected, which is why the British model does not represent an appropriate solution.

In the absence of effective European reforms, the suggested climate and supply market model can therefore offer an alternative way of pricing $\mathrm{CO}_{2}$ on a national basis, internalising the costs of $\mathrm{CO}_{2}$ emissions and clearing market distortions originating from EU ETS allowance prices which are too low without violating international trade agreements or EU law.

\section{Unilateral Climate and Supply Market Model}

It has been shown that, regarding energy policy objectives, further policy measures targeting emission reductions as well as addressing concerns over (long-term) investment incentives are needed. The authors propose a climate and supply market model that tackles not only the aforementioned climate issue but also the insufficient investment incentives provided by the energy-only market.

Given the difficulties in reforming emission trading systems such as the EU ETS at a multilateral level, the climate and supply market model suggests a unilateral approach in which a state introduces a $\mathrm{CO}_{2}$ levy that internalises the external costs of $\mathrm{CO}_{2}$ emissions at a national level. It aims to correct the aforementioned market distortions caused by the low EU ETS price level and its subsequent effects by reintroducing a significant carbon price for the power sector. The model exempts the consumption of $\mathrm{CO}_{2}$-neutral electricity from the new $\mathrm{CO}_{2}$ levy, using national guarantees of origin (which already exist in many countries). The levy is introduced for suppliers who pass the costs on to the final electricity consumers (Fig. 1). The EU ETS allowance price is taken into account, whereby the proposed $\mathrm{CO}_{2}$ levy decreases when the EU ETS allowance price rises. The government, relevant ministry or institution in question sets the amount of the national $\mathrm{CO}_{2}$ levy. This amount could be related to the social costs of carbon ${ }^{12}$ or, if available, existing $\mathrm{CO}_{2}$ taxation on fuels.

\footnotetext{
${ }^{12}$ The social costs of carbon are a scientific approach to measure the marginal costs of emitting an additional unit of $\mathrm{CO}_{2}$ or $\mathrm{CO}_{2}$ equivalents at a given time. The comprehensive scientific approach tries to incorporate climate change-related costs to estimate the social costs of carbon. See Committee on Assessing Approaches to Updating the Social Cost of Carbon et al. (2017) for a recent overview of social costs of carbon estimates.
} 


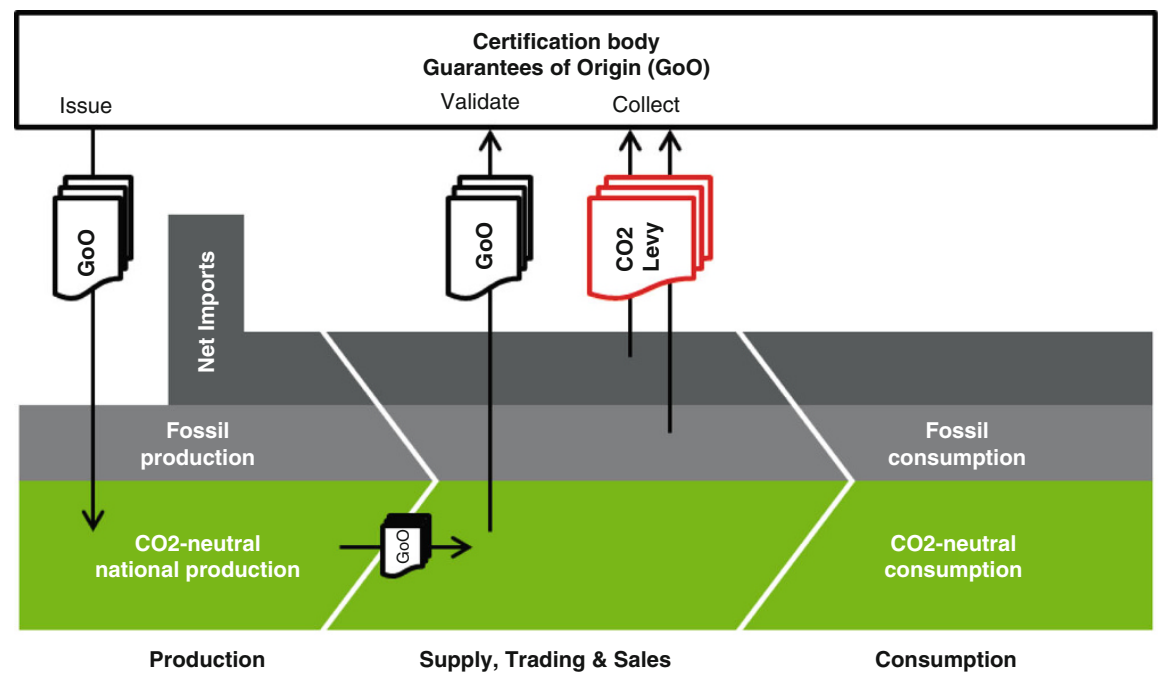

Fig. 1 Climate and supply market model

In the suggested model, producers report their production to a certification body (in many cases already existing and responsible for handling guarantees of origin) and receive corresponding guarantees or certificates. Suppliers report to the certification body their deliveries to the final consumers, and they pay the corresponding $\mathrm{CO}_{2}$ levy or present national guarantees of $\mathrm{CO}_{2}$-neutral origin instead. ${ }^{13}$ Guarantees of origin are traded, and as long as national $\mathrm{CO}_{2}$-neutral production does not surpass the national demand, the guarantee price should roughly equal the $\mathrm{CO}_{2}$ levy, since suppliers have either to pay the $\mathrm{CO}_{2}$ levy or present the guarantees of $\mathrm{CO}_{2}$-neutral origin. ${ }^{14}$ It should be noted at this point that the certificate market remains independent and separate from the energy-only market on which electricity is traded.

In order not to discriminate against any form of production (thus adopting a principle of non-discrimination), the $\mathrm{CO}_{2}$ levy applies generally to every unit of electricity consumed within the country and does not differentiate between technologies - apart from the fact that only guarantees of origin from $\mathrm{CO}_{2}$ neutral sources offer an exemption from the levy. Costs associated with $\mathrm{CO}_{2}$ (such as the social costs of carbon) are usually expressed per tonne of $\mathrm{CO}_{2}$. For the purpose of the climate and supply market model, a calculation to express the costs per unit of electricity (i.e. MWh) is necessary. The $\mathrm{CO}_{2}$ intensity of either the national power sector or a European Economic Area (EEA) average can be

\footnotetext{
${ }^{13} \mathrm{It}$ is assumed that foreign guarantees of origin cannot offer exemptions as long as there is no such agreement.

${ }^{14}$ If national production exceeds final national consumption, the guarantees of origin have no additional value.
} 
used for this, resulting in the following formula which also incorporates the EU ETS:

$$
\begin{aligned}
& \left(\mathrm{CO}_{2} \text { levy }\left[\frac{\mathrm{EUR}}{\mathrm{tCO}}\right]-\mathrm{EU} \text { ETS price }\left[\frac{\mathrm{EUR}}{\mathrm{tCO}_{2}}\right]\right) * \mathrm{CO}_{2} \text { intensity }\left[\frac{\mathrm{tCO}_{2}}{\mathrm{MWh}}\right] \\
& =\mathrm{CO}_{2} \text { levy }\left[\frac{\mathrm{EUR}}{\mathrm{MWh}}\right] .
\end{aligned}
$$

Consequently, the final $\mathrm{CO}_{2}$ levy decreases if the EU ETS allowance price rises or the $\mathrm{CO}_{2}$ intensity is reduced. In terms of decarbonisation, this means the model is designed to eventually become redundant if the decarbonisation of the power sector progresses and/or EU ETS reforms lead to a higher level of allowance prices. ${ }^{15}$ In order to reach the objective of a $\mathrm{CO}_{2}$-neutral supply covering national demand, the guarantees of origin remain valid only for a specific period of time. This ensures that the investment incentives are set in a way that incentivises $\mathrm{CO}_{2}$-neutral production when it is insufficient to cover national demand. In this way, the climate and supply market model strengthens security of supply and makes a country less dependent on imports. As soon as $\mathrm{CO}_{2}$-neutral sources satisfy the national demand during the chosen time periods, the model becomes obsolete. In the case of renewable power plants that are currently supported through some form of renewable support mechanism such as feed-in tariffs or quota schemes, the support scheme administrative authority (rather than the plant operator) should receive the certificates. ${ }^{16}$ Those guarantees can then be sold on the market and used, for example, to finance the costs of the existing renewable support scheme.

Currently, several governments in Europe have some form of $\mathrm{CO}_{2}$ levy in place usually concerning fuels used in the transport or heating sector. ${ }^{17}$ The emissions originating from electricity generation for electric radiators or vehicles is, in contrast, often only charged through EU ETS, and there is no true cross-sector approach. $\mathrm{CO}_{2}$ levies for fuels could be used and applied to other sectors, in order to implement a cross-sector carbon price. Such a cross-sector approach would help to clear market distortions and effectively reward the most carbon-efficient approach in fields such as heating or mobility. Introducing the climate and supply market model inevitably leads to higher electricity bills for consumers, due to its financing structure. The

\footnotetext{
${ }^{15}$ The EU ETS allowance price used in the formula can be determined by either using past (ex post) or future (ex ante) allowance prices.

${ }^{16}$ This is done to prevent windfall profits for operators of renewable power plants already supported through some form of support mechanism as the value of the guarantees of origin would increase significantly through the introduction of the climate and supply market model. Those operators will have to be compensated in some way as they will not be able to sell their guarantees of origin. A direct financial compensation and an introduction of new distinct certificates serving the same purpose as guarantees of origin yet not eligible for the climate and supply market model would be possible ways of doing so.

${ }^{17}$ Examples of carbon taxes can be found in Switzerland, Sweden, Finland and Denmark (see World Bank et al. 2016).
} 
exact costs would be country specific and depend amongst other things on the set $\mathrm{CO}_{2}$ levy, the country's electricity generation mix, the import/export balance, the potential exemptions of some customers and the final consumption of electricity. In this regard, the test case presented later shows an acceptable level of costs for consumers.

Aside from the additional cost burden that comes with the climate and supply market model, one should also address the drawbacks that a uniform $\mathrm{CO}_{2}$ levy entails. In order not to discriminate against certain forms of production, the $\mathrm{CO}_{2}$ levy of the climate and supply market model is uniform and applicable to all forms. Guarantees of origin offer exemptions only for electricity produced from $\mathrm{CO}_{2}$ neutral sources, which in turn means that all electricity produced from fossil sources faces the same uniform $\mathrm{CO}_{2}$ levy. Electricity from emission-intensive lignite- or coal-fired power plants is thus not treated differently than that produced from less emission-intensive gas-fired and combined-cycle power plants. This consequently makes the climate and supply market model an ill-fitted model for countries that seek to replace coal-fired generation capacities with gas-fired capacities through the introduction of a $\mathrm{CO}_{2}$ levy.

\section{Legal Considerations with Respect to International and EU Law}

The concept of pricing $\mathrm{CO}_{2}$ on a unilateral level is not new, and there have been various studies regarding its legal status in the past. ${ }^{18}$ In order to initiate a public debate on a concept such as the suggested climate and supply market model, it is necessary to clarify the legal considerations such a market design entails. Any potential market design has to be compatible with existing legislation and in particular with WTO law, EU law and other trade agreements, since $\mathrm{CO}_{2}$ taxation regimes have to be carefully designed in order not to violate them. A professional legal assessment of the suggested climate and supply market model by a leading Swiss law firm found the model to be in line with all relevant international and EU legislations.

Fundamental for the legal compatibility of the suggested model is the twofold approach of putting a levy on the final electricity consumption (rather than production) and the clear separation of the national guarantees of origin market on the one hand and the energy-only market on the other. Generally, guarantees of origin are not considered goods or products under internal trade law since they are not tangible and have no customs tariff number in the Harmonized Commodity and Coding Systems (short Harmonized System [HS]) of international law (Petsonk 1999,

\footnotetext{
${ }^{18}$ See, for instance, Cottier et al. (2011, 2014a), Holzer (2014), Panezi (2015).
} 
pp. 199-200). ${ }^{19}$ They are also generally not considered as services under the General Agreement on Trade in Services (GATS) even though the subsequent trading of the certificates may be regarded as such (Delimatsis and Mavromati 2009, p. 251).

Also as concerns EU law, guarantees of origin are not handled as goods which fall under the free movement of goods within the single market. Court rulings by the European Court of Justice underline that green certificates or guarantees of origin are not treated as goods and that guarantees do not have to be recognised by other member states. One can refer at this point to the prominent case of Alland Vindkraft and a following similar case relating inter alia to Belgian guarantees of origin.

The Alland Vindkraft court ruling (which gained prominence by confirming the national character of renewable support schemes) clarified that member states only have to recognise foreign guarantees of origin to a limited extent (European Court of Justice 2014a, p. 11). In a similar case, one of the involved parties explicitly argued that the intangible nature of guarantees of origin prevents their categorisation as goods. The court refrained hereby from ruling definitely, answering that 'even if it were accepted that guarantees of origin ... constitute "goods" it would not change the question at stake (European Court of Justice 2014b, p. 15). Accordingly, it is fair to say that thus far, guarantees of origin have not been treated as goods in international law and EU law, which is crucial for the legal compatibility of the suggested climate and supply market model.

Finally, as regards this legal perspective, it is worth taking a brief look at the EU state aid law vis-a-vis the suggested model. The support of companies or industries with state resources is considered state aid by the European Commission. The legal assessment asserts that the climate and supply market model does not constitute state aid. The associated costs arising through the $\mathrm{CO}_{2}$ levy of the suggested model are borne by consumers, and the amounts paid for the $\mathrm{CO}_{2}$ levy are not received by producers. The fact that the value of guarantees of origin experiences a substantial increase through a state intervention does not change this principle. Strictly speaking, the model does therefore not constitute state aid in this context. However, even if the model was considered state aid, it would likely be considered proportionally and approvable (similar to other permitted measures). This should be seen in the broader context of approved measures regarding support for renewables and mechanisms strengthening the security of supply.

\footnotetext{
${ }^{19}$ It should be noted that there is no clear definition of what exactly constitutes a good in international law and, thus far, guarantees of origin or certificates as part of renewable support schemes (often referred to as quota obligation or green certificates) have not been regarded as goods or services (Buchmüller 2013; Delimatsis and Mavromati 2009; Howse 2009; Petsonk 1999).
} 


\section{Climate and Supply Market Model Example: Switzerland}

One can use Switzerland as an example to illustrate the proposed climate and market model. Switzerland's domestic power production is virtually $\mathrm{CO}_{2}$ neutral. Yet during the winter months, Switzerland relies on imports to meet its demand. The validity for guarantees of origin could therefore be set for 1 month. During summer months, when Switzerland is a net exporter of electricity, the guarantees of origin from $\mathrm{CO}_{2}$-neutral sources would be without additional value, and no $\mathrm{CO}_{2}$ levy applies. However, in winter months when Switzerland imports electricity, the value of guarantees of origin from $\mathrm{CO}_{2}$-neutral sources would rise to approximately that of the $\mathrm{CO}_{2}$ levy to be paid for non- $\mathrm{CO}_{2}$-neutral production (i.e. imports). Existing Swiss laws include a $\mathrm{CO}_{2}$ levy on thermal fuels of $84 \mathrm{CHF} / \mathrm{tCO}_{2}(\approx 78$ EUR/tCO $\mathrm{CO}_{2}$ ) (Federal Office for the Environment 2016; Bundesrat 2011). The suggestion is to apply the same carbon price level to the power sector. Consequently, in winter months when imports are necessary, suppliers would need to pay the $\mathrm{CO}_{2}$ levy for the electricity that cannot be exempted with guarantees of origin (imports).

For the calculation of the applicable $\mathrm{CO}_{2}$ levy, an estimated average $\mathrm{EEA}^{20}$ power generation carbon intensity of $0.23 \mathrm{tCO}_{2} / \mathrm{MWh}^{21}$ can be used. To take the EU ETS price into account that has already been paid, one can deduct the EU ETS allowance price off the Swiss carbon price. With a carbon price of $78 \mathrm{EUR} / \mathrm{tCO}_{2}$ and a 2016 average EU ETS allowance price of about $5.3 \mathrm{EUR} / \mathrm{tCO}_{2}$, the suggested $\mathrm{CO}_{2}$ levy would thus equal:

$$
\left(78\left[\frac{\mathrm{EUR}}{\mathrm{tCO}_{2}}\right]-5.3\left[\frac{\mathrm{EUR}}{\mathrm{tCO}_{2}}\right]\right) * 0.23\left[\frac{\mathrm{tCO}_{2}}{\mathrm{Mwh}}\right]=16.7\left[\frac{\mathrm{EUR}}{\mathrm{MWh}}\right] .
$$

Swiss suppliers would therefore have the choice of either buying national guarantees of origin from $\mathrm{CO}_{2}$-neutral sources or paying the $\mathrm{CO}_{2}$ levy. Given the certificate scarcity in import months (i.e. when Swiss national $\mathrm{CO}_{2}$-neutral production does not cover demand), the price for the guarantees of origin would equal that of the $\mathrm{CO}_{2}$ levy of 16.7 EUR/MWh-since for every MWh delivered suppliers have to provide either a guarantee of origin or pay the $\mathrm{CO}_{2}$ levy.

An increase of the EU ETS allowance price level or a decrease of the EEA power generation carbon intensity leads to a lower $\mathrm{CO}_{2}$ levy without further adjustments. In

\footnotetext{
${ }^{20} \mathrm{An}$ EEA plus Switzerland average rather than EU average is used here for legal reasons. The economic area of the EEA plus Switzerland encompasses a wider European market and does not discriminate specific countries or on the basis of political union.

${ }^{21}$ Estimation based on a published EU CO2 emission intensity of $0.276 \mathrm{tCO}_{2} / \mathrm{MWh}$ for 2014 (European Environment Agency 2016). Assuming a similar $\mathrm{CO}_{2}$ emission intensity reduction as in previous years and taking the virtually $\mathrm{CO}_{2}$-free Swiss, Norwegian, Icelandic and Liechtenstein production into account to form an EEA + Switzerland average, one can use $0.23 \mathrm{tCO}_{2} / \mathrm{MWh}$ as a rough estimation for 2016 (Amt für Statistik 2016, p. 18; European Environment Agency 2016; Norwegian Water Resources and Energy Directorate (NVE) 2017; Orkustofnun, 2017, p. 1; Swissgrid 2017).
} 
summer months, when Switzerland is traditionally an exporter of electricity and its domestic $\mathrm{CO}_{2}$-neutral production exceeds consumption, the guarantees of origin have no additional value.

This example shows that the climate and supply market model would reward $\mathrm{CO}_{2}$-neutral production in times when the national $\mathrm{CO}_{2}$-neutral production is not sufficient to cover the demand and set incentives for expanding capacities that produce $\mathrm{CO}_{2}$-neutral electricity during those times.

A subsequent step is to calculate the economic impact and overall costs arising from a $\mathrm{CO}_{2}$ levy of $16.7 \mathrm{EUR} / \mathrm{MWh}$. Over the last 5 years (2012-2016), there were on average 4 months per year during which the final electricity consumption was greater than the total energy production in Switzerland (Swissgrid 2017).

The average final electricity consumption over those 4 months equalled

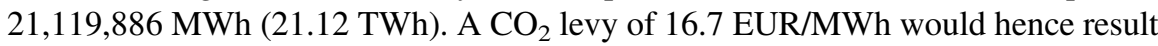
in costs of around 353 million EUR per year. It should be noted at this point that this sum may vary depending mostly on the number of months during which the final electricity consumption exceeds the production of $\mathrm{CO}_{2}$-neutral electricity. The total annual Swiss final electricity consumption has been just below $60 \mathrm{TWh}$ in the last couple of years (Bundesamt für Energie 2017, p. 4). The costs of 350 million EUR per year would thus equal additional costs of around 0.6 cents $/ \mathrm{kWh}$, which can arguably be seen as an acceptable level of additional costs.

\section{Variations of the Climate and Supply Market Model}

The model can be altered in many ways to incorporate specific requirements or change its effects. The most straightforward steering instrument is the governmentset $\mathrm{CO}_{2}$ levy in EUR/tCO carbon intensity translates into the final levy expressed in EUR/MWh. Policymakers can choose whichever price is perceived as appropriate to work towards the given policy objectives. This might result in a cross-sector carbon price as in the described example or one that relates to the social costs of carbon.

One recurring aspect of $\mathrm{CO}_{2}$ taxation regimes are exemptions or special conditions for energy-intensive industries. Such measures can be included in the suggested climate and supply market model in case policymakers choose not to place additional burdens on the energy-intensive industry.

It may also be in the interest of a government to choose which particular $\mathrm{CO}_{2^{-}}$ neutral generation technologies should profit from the guarantees of origin value increase. It could, for example, be restricted to $\mathrm{CO}_{2}$-free rather than $\mathrm{CO}_{2}$-neutral technologies thereby excluding technologies such as biomass or landfill power plants.

Another central element of the suggested model is the time period for which guarantees remain valid. In the presented example, the time period is set to 1 month, but different time frames are possible. Depending on the country's requirements and circumstances, the administrative body could set a longer time frame (i.e. quarters or 
seasons) or shorter one (i.e. weeks, days or even hours). A shorter time frame represents a more precise steering instrument but increases potential market power abuses. $^{22}$ Additionally, it comes at higher administrative costs and efforts for market participants and the administrative body.

In the suggested version of the model, suppliers have to provide one guarantee of origin from $\mathrm{CO}_{2}$-neutral production for every $\mathrm{MWh}$ delivered or pay the $\mathrm{CO}_{2}$ levy. But the administrative body could also require suppliers to provide more or less than one guarantee per unit of energy delivered. This way, one could steer the demand for guarantees and it enables setting targets of a desirable share of production from $\mathrm{CO}_{2}$ neutral sources for the chosen time period.

\section{Adaption Potential for the Climate and Supply Market Model}

The concept of the climate and supply market model was developed in a European context, and the focus of this research rested on European countries. The general principle of a $\mathrm{CO}_{2}$ price component with exemptions for $\mathrm{CO}_{2}$-neutral production using guarantees of origin can theoretically also be applied elsewhere. Naturally this would entail some necessary adaptions such as the removal of the EU ETS pricing in the formula of the $\mathrm{CO}_{2}$ levy and further legal assessments.

The model is particularly attractive for countries with a high share of traditional $\mathrm{CO}_{2}$-neutral production (e.g. hydro, biomass) and looking for ways to maintain or increase it. Newer forms of $\mathrm{CO}_{2}$-neutral/free production such as photovoltaics (PV) and wind are commonly supported through some form of feed-in scheme. As mentioned, operators of plants receiving subsidies through such a scheme would not be eligible for support through the climate and supply market model, since it would result in windfall profits.

With compensation levels of support schemes continuously decreasing due to the cost reductions of renewables technologies, learning curves and further innovation, one may question for how long governments will continue their feed-in support schemes. Recent competitive tenders have again led to a decrease in compensation levels, and the first German offshore wind auction gained prominence as companies

\footnotetext{
${ }^{22}$ If in a chosen time period domestic $\mathrm{CO}_{2}$-neutral production is projected to be only marginally greater than the final consumption, producers might abuse their market power to transform it into an import period by withholding generation capacity. This could increase their income as the value of the guarantees of origin from $\mathrm{CO}_{2}$-neutral sources would rise to that of the $\mathrm{CO}_{2}$ levy. The shorter the time period, the smaller the generation capacity necessary to do so, as long as market data are available to project if domestic production will exceed or fall short of final consumption.
} 
bid to build offshore wind parks without a guaranteed minimum strike price. ${ }^{23}$ In this light, it seems plausible that policymakers discuss the future of support schemes with the climate and supply market model comprising a potential option.

Since the climate and supply market model aims to incentivise $\mathrm{CO}_{2}$-neutral power production during times when the targeted share of this production type is not met, it seems most apt for countries that already have a relatively high share of $\mathrm{CO}_{2}$-neutral production in their electricity mix. Aside from the aforementioned example of Switzerland, the following European countries have a large $\mathrm{CO}_{2}$-neutral share (over 65\%) in their gross electricity production (according to data published by the European Commission 2017): Austria, Croatia, Denmark, Finland, France, Slovakia, Slovenia and Sweden.

Given the functioning of the climate and supply market model described herein, the composition of the power sectors of these countries make them ideal candidates for a potential adaption of the model or discussion thereof. This is not to say that the climate and supply market model is not a useful fit for other countries. If policymakers set a lower amount of required guarantees of origin for suppliers per MWh delivered (e.g. 0.5 rather than 1), the model can also be attractive for countries with a lower share of $\mathrm{CO}_{2}$-neutral production. As mentioned earlier, the fact that the $\mathrm{CO}_{2}$ levy of the model is uniform means that all electricity is treated the same independent of exact $\mathrm{CO}_{2}$ intensity of the production and only guarantees of origin from $\mathrm{CO}_{2}$-neutral sources offer exemptions. Therefore, the model does not represent an adequate instrument for countries that seek to introduce a $\mathrm{CO}_{2}$ levy to lift the economic viability of gas-fired power generation over that of coal-fired generation.

\section{Conclusion}

It has been argued that the power sector is facing a series of difficulties in light of energy transitions and decarbonisation. Low EU ETS allowance prices have led to a state of uncertainty regarding its role as a driver for decarbonisation. Previous reform processes have had limited success, and some countries have looked towards unilateral action to tackle the issue.

A run of very low wholesale power prices in Europe, partly caused by low EU ETS allowance prices, has led to concerns over long-term generation adequacy (the 'missing money problem') and the introduction of capacity remuneration mechanisms to counter the issue. The authors propose a unilateral climate and supply market model to address these aforementioned concerns. The model's core component is an introduction of a $\mathrm{CO}_{2}$ levy on final electricity consumption. Exemptions

\footnotetext{
${ }^{23}$ In 2017, EnBW and Dong Energy were awarded the right to build wind farms in the North Sea with submitted bids of 0 EUR/MWh. It should be noted that they will still receive some form of subsidy as they gained the right to operate those parks for 25 years and network charges for electricity consumers finance the costly grid connection(s) (Bundesnetzagentur 2017, p. 2).
} 
from the levy are offered for electricity produced from $\mathrm{CO}_{2}$-neutral sources. Suppliers have to provide guarantees of origin from $\mathrm{CO}_{2}$-neutral production for every MWh delivered or pay the $\mathrm{CO}_{2}$ levy. The government sets the amount of the levy, and the time period guarantees of origin remain valid for. This way the climate and supply market model incentivises the power production from $\mathrm{CO}_{2}$-neutral sources during times when it does not cover demand or the target share of production.

The model can be used to implement a cross-sector carbon price as the analysis of the example of Switzerland illustrates. The example also shows that the model can be realised at an acceptable level of costs for consumers even though the exact costs depend on a number of the factors discussed, first and foremost the set $\mathrm{CO}_{2}$ levy.

$\mathrm{CO}_{2}$ pricing schemes targeting the power sector have to be carefully designed in order to comply with international and EU law. Some models, such as the British model, therefore exclude electricity imports from their $\mathrm{CO}_{2}$ price floor. In other countries with greater transfer capacity to grids abroad, excluding imports would disproportionally disadvantage domestic power producers, which is why the British model only has limited adaption potential abroad. A legal assessment of the proposed climate and supply market model came to the conclusion that the suggested design complies with relevant legal frameworks.

The model offers various steering instruments for policymakers, and it can be altered to suit a given country. Aside from setting the level of the $\mathrm{CO}_{2}$ levy, the government can specify the time period for which guarantees of origin remain valid and impose the number of guarantees of origin required for suppliers per MWh delivered. Together, these mechanisms enable the government to work towards a targeted share of $\mathrm{CO}_{2}$-neutral production during any time period and incentivise the deployment of additional $\mathrm{CO}_{2}$-neutral generation capacity.

Finally, even though the model has been developed in a European context, the general principle could also be used elsewhere. Within Europe, there are several countries for which the proposed climate and supply market model might represent a potential policy option.

\section{References}

Abbott, M. (2001). Is the security of electricity supply a public good? The Electricity Journal, 14 (7), 31-33.

Abrell, J., Rausch, S., \& Yonezawa, H. (2016). Higher price, lower costs? Minimum prices in the EU emissions trading scheme (SSRN Scholarly Paper No. ID 2764155). Rochester, NY: Social Science Research Network. Retrieved from https://papers.ssrn.com/abstract=2764155

Amt für Statistik. (2016). Energiestatistik 2015. Vaduz: Fürstentum Liechtenstein. Retrieved from http://www.llv.li/files/as/energiestatistik-2015.pdf

Ares, E., \& Delebarre, J. (2016). The carbon price floor. London: House of Commons Library.

Aurora Energy Research. (2016). Dash for interconnection: The impact of interconnectors on the GB market. Oxford: Aurora Energy Research. Retrieved from https://www.auroraer.com/wpcontent/uploads/2016/10/Dash-for-Interconnectors-Aurora-Energy-Research-February-2016.pdf

Boffey, D. (2017). Reform of EU carbon trading scheme agreed. The Guardian. Retrieved from https://www.theguardian.com/environment/2017/feb/28/reform-of-eu-carbon-trading-schemeagreed 
Bublitz, A., Keles, D., \& Fichtner, W. (2017). An analysis of the decline of electricity spot prices in Europe: Who is to blame? Energy Policy, 107, 323-336.

Buchmüller, C. (2013). Strom aus erneuerbaren Energien im WTO-Recht. Baden-Baden: Nomos Verlagsgesellschaft mbH \& Co. KG.

Bundesamt für Energie (BFE). (2017). Schweizerische Elektrizitätsstatistik 2016. Bern: Schweizerische Eidgenossenschaft. Retrieved from http://www.bfe.admin.ch/php/modules/ publikationen/stream.php?extlang $=$ de\&name $=$ de_306571764.pdf\&endung $=$ Schweizerische $\%$ 20Elektrizit\%E4tsstatistik\%202016

Bundesnetzagentur. (2017). Press release: Bundesnetzagentur announces successful bids in first auction for offshore wind farms. Bundesnetzagentur. Retrieved from https://www. bundesnetzagentur.de/SharedDocs/Downloads/EN/BNetzA/PressSection/PressReleases/2017/ 13042017_windsee.pdf?_blob $=$ publicationFile \& $\mathrm{v}=2$

Bundesrat. (2011). Bundesgesetz über die Reduktion der CO2-Emissionen (CO2-Gesetz). Retrieved from https://www.admin.ch/opc/de/official-compilation/2012/6989.pdf

Carbon Market Watch. (2015). Four magic potions to turn the EU ETS into an effective climate mitigation tool (Policy Brief) (pp. 1-8). Brussels. Retrieved from http://carbonmarketwatch.org/ four-magic-potions-to-turn-the-eu-ets-into-an-effective-climate-mitigation-tool/

Clark, P. (2017). UK carbon emissions fall to late-19th century levels. Retrieved from https://www. ft.com/content/2bc62cb8-004f-11e7-8d8e-a5e3738f9ae4

Committee on Assessing Approaches to Updating the Social Cost of Carbon, Board on Environmental Change and Society, Division of Behavioral and Social Sciences and Education, \& National Academies of Sciences, Engineering, and Medicine. (2017). Valuing climate changes: Updating estimation of the social cost of carbon dioxide. Washington, D.C.: National Academies Press. https://doi.org/10.17226/24651.

Cottier, T., Delimatsis, P., Malumfashi, G., Matteotti-Berkutova, S., Nartova, O., De Sépibus, J., \& Bigdeli, S. Z. (2011). Energy in WTO law and policy. In The prospects of international trade regulation: From fragmentation to coherence (pp. 211-244). Cambridge: Cambridge University Press.

Cottier, T., Espa, I., Hirsbrunner, S., Holzer, K., \& Payosova, T. (2014a). Differentiating energy tax on electricity: An assessment of the compatibility with WTO law and EU law (Legal Opinion submitted to the Swiss Federal Financial Administration (FFA), the Swiss State Secretariat for Economic Affairs (SECO) and the Swiss Federal Office of Energy (SFOE)). Bern: University of Bern.

Cottier, T., Espa, I., Hirsbrunner, S., Holzer, K., \& Payosova, T. (2014b). $\mathrm{CO}_{2}$ levies and tariffs on imported electricity. Bundesamt für Energie BFE.

Cottier, T., Espa, I., Hirsbrunner, S., Holzer, K., \& Payosova, T. (2014c). Differential taxation of electricity: Assessing the compatibility with WTO law, EU law and the Swiss-EEC free trade agreement (Legal Opinion submitted to the Swiss Federal Financial Administration (FFA), the Swiss State Secretariat for Economic Affairs (SECO) and the Swiss Federal Office of Energy (SFOE)). Bern: Swiss Federal Office of Energy (SFOE). Retrieved from https://www.seco. admin.ch/dam/seco/de/dokumente/Publikationen_Dienstleistungen/Publikationen_Formulare/ Umwelt_Energie/Vereinbarte\%20differenzierte\%20Stromsteuer.pdf.download.pdf/ES2050\% 20zweite\%20Etappe.\%20differenzierte\%20Stromsteuern.pdf

Crampton, P., \& Stoft, S. (2006). The convergence of market designs for adequate generating capacity. White paper for the California Electricity Oversight Board. Retrieved from http:// www.cramton.umd.edu/papers2005-2009/cramton-stoft-market-design-for-resource-adequacy. pdf

De Vries, L. J., \& Hakvoort, R. A. (2003). The question of generation adequacy in liberalized electricity markets. Presented at the 26th Annual Conference International Association Energy Economics, Prague: IAEE. Retrieved from https://www.ecn.nl/fileadmin/ecn/units/bs/INDES/ indes-ldv_paper.pdf

Delimatsis, P., \& Mavromati, D. (2009). GATS, financial services and trade in renewable energy certificates (RECs) - Just another market based solution to cope with the tragedy of the commons? In International Trade Regulation and the Mitigation of Climate Change. Cambridge: Cambridge University Press. 
Doukas, H., Patlitzianas, K. D., Kagiannas, A. G., \& Psarras, J. (2008). Energy policy making: An old concept or a modern challenge? Energy Sources, Part B: Economics, Planning, and Policy, 3, 362-371.

European Commission. (2014). Proposal for a decision of the European Parliament and of the Council concerning the establishment and operation of a market stability reserve for the Union greenhouse gas emission trading scheme and amending Directive 2003/87/EC /* COM/2014/ 020 final - 2014/0011 (COD) *. Brussels: European Commission. Retrieved from http://eur-lex. europa.eu/legal-content/EN/TXT/HTML/?uri=CELEX:52014PC0020\&from=en

European Commission. (2016). Final report of the sector inquiry on capacity mechanisms. Brussels: European Commission. Retrieved from http://ec.europa.eu/energy/sites/ener/files/docu ments/com2016752.en_.pdf

European Commission. (2017). Energy statistics. Brussels: European Commission. Retrieved from https://ec.europa.eu/energy/sites/ener/files/documents/countrydatasheets_march2017.xlsx

European Council. (2017). Revision of the emissions trading system: Council agrees its positionConsilium. Retrieved from http://www.consilium.europa.eu/en/press/press-releases/2017/02/ 28-ets-revision/

European Court of Justice. Case C-204/12 Essent Belgium. (2014a). Retrieved from http://curia. europa.eu/juris/document/document.jsf; jsessionid=9ea7d2dc30d642600f97ae054509900d9ede49291c2f. e34KaxiLc3qMb40Rch0SaxyLbN50?text $=\&$ docid $=157525 \&$ pageIndex $=0 \&$ doclang $=E N \&$ mode $=1$ st $\&$ dir $=\& o c c=$ first $\&$ part $=1 \&$ cid $=242997$

European Court of Justice. Case C-573/12 Åland Vindkraft, C-573/12 §. (2014b). Retrieved from http://curia.europa.eu/juris/document/document.jsf?text $=\&$ docid $=154403 \&$ pageIndex $=0 \&$ doclang $=\mathrm{EN} \&$ mode $=1$ st\&dir $=\&$ occ $=$ first $\&$ part $=1 \& \operatorname{cid}=125045$

European Environment Agency. (2016). Overview of electricity production and use in Europe. Retrieved from https://www.eea.europa.eu/data-and-maps/daviz/co2-emission-intensity-3

Everts, M., Huber, C., \& Blume-Werry, E. (2016). Politics vs markets: How German power prices hit the floor. The Journal of World Energy Law \& Business, 9(2), 116-123.

Federal Office for the Environment. (2016). Imposition of the $\mathrm{CO}_{2}$ levy on thermal fuels. Retrieved from https://www.bafu.admin.ch/bafu/en/home/topics/climate/info-specialists/climate-policy/ co2-levy/imposition-of-the-co2-levy-on-thermal-fuels.html

Finon, D., \& Pignon, V. (2008). Electricity and long-term capacity adequacy: The quest for regulatory mechanism compatible with electricity market. Utilities Policy, 16(3), 143-158.

Hancher, L., de Hauteclocque, A., \& Sadowska, M. (2015). Capacity mechanisms in the EU energy market: Law, policy, and economics. Oxford: OUP.

Hepburn, C., Neuhoff, K., Acworth, W., Burtraw, D., \& Jotzo, F. (2016). The economics of the EU ETS market stability reserve. Journal of Environmental Economics and Management, 80, 1-5.

Hirth, L. (2016). What caused the drop in European electricity prices? (SSRN Scholarly Paper No. ID 2874841). Rochester, NY: Social Science Research Network. Retrieved from https:// papers.ssrn.com/abstract $=2874841$

HM Revenues \& Customs. (2014). Carbon price floor: Reform and other technical amendments. Retrieved from https://www.gov.uk/government/uploads/system/uploads/attachment_data/file/ 293849/TIIN_6002_7047_carbon_price_floor_and_other_technical_amendments.pdf

HM Treasury. (2016). Autumn statement 2016. Retrieved from https://www.gov.uk/government/ publications/autumn-statement-2016-documents/autumn-statement-2016

Holzer, K. (2014). Carbon-related border adjustment and WTO Law. Cheltenham: Edward Elgar.

Holzer, K., Espa, I., \& Payosova, T. (2017). Promoting Green electricity through differentiated electricity tax schemes. In Cottier \& Espa (Eds.), International trade in sustainable electricity. Cambridge: Cambridge University Press.

Horn, H., \& Mavroidis, P. C. (2011). To B(TA) or Not to B(TA)? On the legality and desirability of border tax adjustments from a trade perspective. The World Economy, 34(11), 1911-1937.

Howard, R. (2016). Next steps for the carbon price floor. London: Policy Exchange. Retrieved from https://policyexchange.org.uk/wp-content/uploads/2016/11/Carbon-Price-Floor-ResearchNote-FINAL3.pdf 
Howse, R. (2009). World Trade Law and renewable energy: The case of non-tariff measures. New York and Geneva: United Nations Conference on Trade and Development. Retrieved from http://unctad.org/en/Docs/ditcted20085_en.pdf

Intercontinental Exchange (ICE). (2017). EUA Futures. Atlanta. Retrieved from https://www. theice.com/products/197/EUA-Futures/data

Ismer, R., \& Neuhoff, K. (2007). Border tax adjustment: A feasible way to support stringent emission trading. European Journal of Law and Economics, 24(2), 137-164. https://doi.org/ 10.1007/s10657-007-9032-8.

Joskow, P. L. (2008). Capacity payments in imperfect electricity markets: Need and design. Utilities Policy, 16(3), 159-170.

Koch, N., Fuss, S., Grosjean, G., \& Edenhofer, O. (2014). Causes of the EU ETS price drop: Recession, CDM, renewable policies or a bit of everything?-New evidence. Energy Policy, 73, 676-685.

Kreiser, L., Andersen, M. S., Olsen, B. E., Speck, S., Milne, J. E., \& Ashiabor, H. (2015). Environmental pricing: Studies in policy choices and interactions. Cheltenham: Edward Elgar.

Kuik, O., \& Hofkes, M. (2010). Border adjustment for European emissions trading: Competitiveness and carbon leakage. Energy Security - Concepts and Indicators with Regular Papers, 38 (4), 1741-1748. https://doi.org/10.1016/j.enpol.2009.11.048.

Lu, B., Ma, X., \& Feng, C. (2015). Theory and model of energy investment and financing. In J. Yan (Ed.), Handbook of clean energy systems, 6 Volume Set. New York: Wiley.

Marcu, A., Elkerbout, M., \& Wijnand, S. (2016). 2016 State of EU ETS Report. Brussels: Centre for European Policy Studies (CEPS). Retrieved from http://www.ceps-ech.eu/sites/default/files/ State\%20of\%20EU\%20ETS\%20v16_0.pdf

Newbery, D. (2016). Missing money and missing markets: Reliability, capacity auctions and interconnectors. Energy Policy, 94, 401-410.

Nikas, A., Doukas, H., \& López, L. M. (2018). A group decision making tool for assessing climate policy risks against multiple criteria. Heliyon, 4.

Norwegian Water Resources and Energy Directorate (NVE). (2017). Norway and the European power market. Retrieved from https://www.nve.no/energy-market-and-regulation/wholesalemarket/norway-and-the-european-power-market/

Ofgem. (2017). Electricity interconnectors. Retrieved from https://www.ofgem.gov.uk/electricity/ transmission-networks/electricity-interconnectors

Orkustofnun. (2017). Development of electricity production in Iceland 2015 (Orkustofnun Data Repository). Reykjavik: Orkustofnun. Retrieved from http://os.is/gogn/Talnaefni/OS-2017T005-01.pdf

Panezi, M. (2015). When $\mathrm{CO}_{2}$ goes to Geneva - Taxing carbon across borders - Without violating WTO obligations. CIGI Papers, 83. Retrieved from https://www.cigionline.org/sites/default/ files/cigi_paper_no.83.pdf

Petsonk, A. (1999). The Kyoto Protocol and the WTO: Integrating greenhouse gas emissions allowance trading into the global marketplace. Duke Environmental Law \& Policy Forum, 10, 185.

Rattay, W. (2017). Emissionshandel: EU-Parlament stimmt für strengere Regeln. Die Zeit. Retrieved from http://www.zeit.de/wirtschaft/2017-02/emissionshandel-eu-parlamentzertifikate-umweltschutz

Rogge, K. S., Schneider, M., \& Hoffmann, V. H. (2011). The innovation impact of the EU Emission Trading System - Findings of company case studies in the German power sector. Ecological Economics, 70(3), 513-523.

Swissgrid. (2017). Energieübersicht Schweiz 2016. Swissgrid. Retrieved from https://www. swissgrid.ch/dam/dataimport/energy_data/de/EnergieUebersichtCH_2016.xls

Sync Ni. (2013). Foster welcomes Chancellor's decision to exempt Northern Ireland generators from Carbon Tax. Retrieved from https://syncni.com/news/2/1459/foster-welcomes-chancellors-decision-to-exempt-northern-ireland-generators-from-carbon-tax/tab/1356 
World Bank, Ecofys, \& Vivid Economics. (2016). State and trends of carbon pricing 2016. Washington, DC: World Bank. Retrieved from https://openknowledge.worldbank.org/handle/ $10986 / 25160$

Open Access This chapter is licensed under the terms of the Creative Commons Attribution 4.0 International License (http://creativecommons.org/licenses/by/4.0/), which permits use, sharing, adaptation, distribution and reproduction in any medium or format, as long as you give appropriate credit to the original author(s) and the source, provide a link to the Creative Commons license and indicate if changes were made.

The images or other third party material in this chapter are included in the chapter's Creative Commons license, unless indicated otherwise in a credit line to the material. If material is not included in the chapter's Creative Commons license and your intended use is not permitted by statutory regulation or exceeds the permitted use, you will need to obtain permission directly from the copyright holder. 